\title{
Analisis Terhadap Motivasi Kerja dan Profesionalitas dalam Mempengaruhi Kinerja Guru di Sekolah Islam Terpadu Bina IImi Palembang
}

\author{
Tri Sinarti \\ Dosen Fakultas Ekonomi Universitas PGRI Palembang \\ email: trisinarti@univpgri-palembang.ac.id
}

\begin{abstract}
ABSTRAK
Penelitian ini bertujuan untuk mengetahui pengaruh motivasi dan profesionalitas terhadap kinerja guru Sekolah Islam Terpadu Bina IImi Palembang. Data yang digunakan dalam penelitian ini berupa data primer dari jawaban 98 responden. Model analisis yang digunakan regresi linear berganda dan melalui pengujian instrumen validitas dan reliabilitas. Uji karakteristik data yaitu uji normalitas dan uji model terdiri dari uji multikolinearitas dan uji heterokesdatisitas. Hasil pengujian regresi linear berganda untuk uji $\mathrm{F}$ menunjukkan terdapat pengaruh positif dan signifikan motivasi kerja dan profesionalitas terhadap kinerja guru sebesar 0,000 . Variabel motivasi kerja berpengaruh signifikan dan positif terhadap kinerja guru dan profesionalitas juga berpengaruh signifikan dan positif terhadap kinerja guru Sekolah Islam Terpadu Bina IImi Palembang. Adanya kesesuaian teori antar variabel dalam penelitian ini dan mendukung penelitian terdahulu. Peningkatan dan penurunan motivasi kerja dan profesionalitas berpengaruh terhadap kinerja guru.
\end{abstract}

Kata kunci : Motivasi kerja, profesionalitas,Kinerja

\section{Pendahuluan}

Keberadaan manajemen dalam mengelola pendidikan sangat penting, karena titik berat manajemen pendidikan terletak pada pengelolaan kependidikan, yaitu mengelola lembaga pendidikan sebagai suatu sistem. Keberhasilan suatu lembaga pendidikan berhubungan dengan manajemen yang diterapkan. Dalam manajemen pendidikan terdapat aktivitas yang mengintegrasikan sumber-sumber pendidikan dengan memusatkan diri pada tujuan yang ditetapkan. Dalam pelaksanaannya ada kerjasama, pembagian tugas, dan kewajiban serta otoritas yang berbeda. Dengan adanya manajemen pendidikan akan mempermudah pelaksanaan kegiatan pendidikan sekaligus memposisikan guru sesuai dengan tugas dan bidang ilmunya.

Peranan guru dalam meningkatkan kualitas pendidikan sangat dominan. Guru harus mampu merencanakan program, melaksanakan program dan mengevaluasi program pembelajaran dengan baik. Guru dituntut memiliki kinerja yang mampu memberikan dan merealisasikan harapan dan keinginan semua pihak terutama masyarakat umum yang telah mempercayai sekolah dan guru dalam membina anak didik. Untuk meraih mutu pendidikan yang baik sangat dipengaruhi oleh kinerja guru dalam melaksanakan tugasnya sebagai pendidik sehingga dapat mencapai keberhasilan pendidikan.

Masalah utama dalam pendidikan terletak pada kinerja guru, kinerja guru menjadi sorotan masyarakat terkait dengan mutu calon intlektual bangsa. Untuk itu peningkatan SDM guru di sekolah merupakan tujuan yang harus terprogram dan terencana oleh pihak sekolah dan pemerintah. Anggapan masyarakat terhadap rendahnya kualitas lulusan seringkali dikaitkan dengan rendahnya kualitas guru. Di lain pihak guru yang memiliki kinerja rendah sering menganggap bahwa sarana dan prasarana pembelajaran yang rendah membuat mereka sulit untuk meningkatkan mutu.

Peningkatan kinerja guru tidak hanya dengan meningkatkan 
kompetensi melalui pemberian penataran, pelatihan dan pengembangan karir, namun peningkatan kinerja guru juga perlu memperhatikan hal lainnya seperti pemberian insentif, gaji yang layak dan profesionalisme sehingga dapat memberikan rasa puas bagi guru dalam bekerja. Rasa puas yang timbul dalam bekerja akan mampu meningkatkan kinerja guru. Uno (2011) menyatakan dalam peningkatan kinerja guru perlu dipertimbangkan melalui peningkataan profesionalitas, motivasi berbentuk pengawasan dan iklim organisasi yang berpihak pada kesejahteraan guru, terbuka dan menekankan pada prestasi, karena tugas guru terkait dan dibuktikan dengan keberhasilan pendidikan siswa.

Menurut Rusman (2010) konsep kinerja guru sebagai cara kerja yang menyangkut kemampuan melaksanakan tugas mengajar dapat dilihat dari indikator meliputi: kemampuan merencanakan program belajar mengajar, kemampuan melaksanakan/mengelola proses belajar mengajar dan kemampuan menilai proses belajar mengajar. Kinerja dapat terbentuk dari pengembangan profesionalitas guru dengan pertimbangan aspek kognitif dan afektif dalam menentukan keberhasilan guru.

Kinerja dapat dipengaruhi oleh motivasi (Hikmat: 2011). Menurut Lunerburg (2000) motivasi sebagai kekuatan berasal dari dalam dan luar diri seseorang, yang menstimulir, mengarahkan perilaku seseorang untuk melakukan suatu tindakan tertentu, demi proses pencapaian prestasi. Motivasi sangat penting ada dalam diri seorang guru, dengan motivasi seorang guru diharapkan mau bekerja keras dan antusias dalam mencapai produktivitas kerja tinggi.
Peningkatan profesional guru akan maksimal jika didukung oleh motivasi yang tinggi. Motivasi sangat penting artinya bagi setiap orang terdorong untuk bekerja keras karena adanya keinginan untuk berprestasi. Selain motivasi, salah satu faktor yang mempengaruhi kinerja yaitu profesionalitas, Mudlofir (2012) menyatakan profesionalitas adalah sebutan terhadap kualitas sikap para anggota suatu profesi terhadap profesinya serta derajat pengetahuan dan keahlian yang mereka miliki untuk dapat melaksanakan tugasnya.

Penerapan kurikulum 13 pada metode pembelajaran di Sekolah Islam Terpadu Bina IImi dan waktu belajar yang full day menuntut guru untuk lebih berkinerja. Sekolah Islam terpadu Bina IImi merupakan sekolah umum dan swasta dibawah naungan yayasan yang terdiri dari sekolah dasar (SD), SMP dan SMA. Yayasan menolak adanya dana bos dari pemerintah untuk biaya operasional sekolah. Artinya semua biaya operasional sekolah direalisasikan dengan menggunakan dana yang bersumber dari uang sekolah siswa. Jumlah siswa tentunya sangat berpengaruh pada jumlah siswa di sekolah ini, untuk itu manajemen sekolah harus mampu meningkatkan kualitas sekolah agar masyarakat percaya menyekolahkan anak di SMP IT Bina IImi. Kualitas sekolah sangat ditentukan dari kualitas lulusan yang tentunya muncul dari hasil proses pembelajaran berkualitas yang dilakukan oleh guru-guru berkualitas.

Berdasarkan latar belakang di atas penulis tertarik untuk membahas permasalahan terkait profesionalitas guru dan motivasi kerja dalam mempengaruhi tingkat kinerja guru di SMP Islam Terpadu Bina IImi Palembang. 


\section{Landasan Teori}

\section{a) Kinerja Guru}

Menurut Uno (2011) kinerja guru adalah hasil yang dicapai secara optimal seorang guru dalam kegiatan mengajarnya. Hasil yang dicapai secara optimal dari tugas mengajar itu merupakan kinerja guru. Selanjutnya Rivai (2009) menyatakan istilah performance sering diartikan sebagai kinerja dan prestasi kerja. Kinerja mempunyai makna lebih luas, bukan hanya menyatakan sebagai hasil kerja, tetapi juga bagaimana proses kerja berlangsung. Menurut Wibowo (2008) kinerja adalah tentang melakukan pekerjaan dan hasil yang dicapai dari pekerjaan tersebut. Kinerja adalah tentang apa yang dikerjakan dan bagaimana mengerjakannya. Mangkunegara (2005) menyatakan kinerja adalah hasil kerja secara kualitas dan kuantitas yang dicapai oleh seorang pegawai dalam melaksanakan tugasnya sesuai dengan tanggung jawab yang diberikan kepadanya. Didukung pendapat Handoko (2009), kinerja merupakan suatu fungsi motivasi dan kemampuan. Untuk menyelesaikan pekerjaan seseorang sepatutnya memiliki derajat kesediaan dan tingkat kemampuan tertentu.

Menurut Uno (2011) indikator kinerja guru terbagi atas lima dimensi yaitu:

a) Kualitas Kerja, kinerja guru dapat dilihat dari cara mengajar dan prestasi yang diperoleh siswa.

b) Kecepatan/Ketepatan Kerja, etepatan kerja merupakan indikator kinerja seorang guru melaksanakan tugasnya.

c) Inisiatif dalam Kerja, selain hasil kerja dan ketepatan kerja inisiatif untuk menghasilkan hal-hal baru juga merupakan kinerja. d) Kemampuan Kerja, kemampuan menggunakan berbagai metode pembelajaran dan memahami fungsi guru.

e) Komunikasi, menafsirkan hasil-hasil penelitian untuk perkembangan pendidikan.

Menurut Robbins (2011), indikator yang dapat digunakan untuk mengukur kinerja pegawai dengan melihat hal-hal berikut:

a) Kualitas Kerja, kualitas kerja diukur dari persepsi karyawan terhadap kualitas pekerjaan yang dihasilkan serta kesempurnaan tugas terhadap keterampilan dan kemampuan karyawan.

b) Kuantitas Kerja, jumlah yang dihasilkan dinyatakan dalam istilah seperti jumlah unit, jumlah siklus aktivitas yang diselesaikan.

c) Ketepatan Waktu, rupakan tingkat aktivitas diselesaikan pada awal waktu yang dinyatakan, dilihat dari sudut koordinasi dengan hasil kerja serta memaksimalkan waktu yang tersedia untuk aktivitas lain.

d) Efektivitas, merupakan tingkat penggunaan sumber daya organisasi (tenaga, uang, teknologi, bahan baku) digunakan untuk meningkatkan hasil dari setiap unit.

e) Kemandirian, merupakan tingkat kemandirian karyawan dalam bekerja, komitmen dan tanggung jawab terhadap lembaga.

\section{b) Motivasi Kerja}

Motivasi mempersoalkan bagaimana caranya mengarahkan daya dan potensi bawahan, agar mau bekerja secara produktif berhasil mencapai dan mewujudkan tujuan yang telah ditentukan. (Malayu: 2014). Motivasi dari kata motif (Motive) atau motivation yang berarti gerakan atau sesuatu yang bergerak. Sesuatu yang menggerakkan terjadinya tindakan atau niat (Hikmat: 2011) Motivasi 
adalah dorongan atau rangsangan yang diberikan kepada seseorang agar memiliki kemauan untuk bertindak. Dapat dilakukan dengan berbagai cara, misalnya meningkatkan upah kerjanya, reward dan imbalan berupa bonus tertentu, aturan-aturan dan sanksi yang ketat bagi pelanggar aturan.

Motivasi juga merupakan keadaan kejiwaan dan sikap mental manusia yang memberikan energi, mendorong kegiatan (moves), dan mengarah atau menyalurkan perilaku kearah mencapai kebutuhan yang memberi kepuasan atau mengurangi ketidakseimbangan. (Siswanto:2007). Motivasi sebagai kekuatan yang berasal dari dalam dan luar diri seseorang. Kekuatan ini yang menstimulir, mengarahkan perilaku seseorang untuk melakukan suatu tindakan tertentu, demi proses pencapaian prestasi.

Dalam sebuah organisasi keberhasilan motivasi kerja seorang pegawai dapat ditentukan oleh tiga komponen, menurut Widodo, (2015) tiga komponen motivasi kerja adalah sebagai berikut:

1) Ekspektasi (harapan) keberhasilan terhadap suatu tugas.

2) Instrumentalis, yaitu penilaian tentang apa yang akan terjadi jika berhasil dalam melakukan suatu (keberhasilan tugas untuk mendapatkan outcome tertentu.

3) Valensi, yaitu respons terhadap outcome seperti perasaan positif, netral, atau negatif. Motivasi tinggi jika usaha menghasilkan sesuatu melebihi harapan dan motivasi rendah apabila usahanya menghasilkan kurang dari yang diharapkan.

Berdasarkan kebutuhannya motivasi kerja dapat dipengaruhi oleh tiga hal penting, Widodo (2015) menyatakan tiga hal penting yang mempengaruhi motivasi:

1) Kebutuhan akan prestasi ( Need for achivement)

2) Kebutuhan akan hubungan sosial ( Need for afiliation)

3) Dorongan untuk mengatur ( Need for power ).

Menurut Lunerburg (2011) terdapat beberapa aspek yang berpengaruh terhadap motivasi kerja pegawai yaitu:

1) rasa aman dalam bekerja,

2) gaji yang adil dan kompetetif,

3) lingkungan kerja yang menyenangkan,

4) penghargaan atas prestasi kerja,

5) perlakuan yang adil dari manajemen.

\section{c) Profesionalitas}

Profesional berasal dari akar kata "professiona" yang jika ditilik dalam kamus Webster dijelaskan sebagai "learned vocation" atau "Vocation that requires learning rather than work with the hands" atau "one who engages in a learned vocatioral" (Rivai: 2009). Dari literatur di atas dapat diperoleh gambaran mengenai karakteristik sikap profesional yaitu:

a) Seorang yang profesional memecahkan masalah dengan pendekatan ilmiah, yakni objektif, logic, sistematik dan metodik. Dapat diuji secara berulang-ulang dengan hasil yang sama (reliable).

b) Berdasarkan ilmu profesi maupun profesional dapat di pelajari. Dibalik kemampuan profesi, pelaku dapat lebih banyak memanfaatkan hasil pembelajaran dari pada keterampilan tangan.

c) Sikap profesionalisme untuk menggambarkan bagaimana seseorang dalam memecahkan permasalahan yang dihadapi pekerjaannya. 
Menurut Hikmat (2011) seseorang dianggap sebagai tenaga profesional apabila dalam mengerjakan tugasnya, ia selalu berpegang teguh pada etika kerja, independen, efektif, efisien, dan inovatif serta didasarkan pada prinsipprinsip pelayanan prima yang didasarkan pada unsur-unsur:

a) IImu atau teori yang sistematis

b) Kewenangan profesional yang diakui klien

c) Sanksi dan pengakuan masyarakat akan keabsahan kewenangannya

d) Kode etik yang regulatif.

Mudlofir (2012) menyatakan profesionalitas adalah sebutan terhadap kualitas sikap para anggota suatu profesi terhadap profesinya serta derajat pengetahuan dan keahlian yang mereka miliki untuk dapat melaksanakan tugas-tugasnya. Selanjutnya Rivai (2009) menyatakan dari pendekatan melalui batasan dan profesionalisme dapat dirumuskan bahwa seseorang dapat disebut sebagai profesional apabila memenuhi syarat-syarat sebagai berikut:

a) Memiliki "knowledge" yang diperlukan oleh seorang yang profesional.

b) Memiliki "Skill" yang diperlukan

c) Senantiasa bersikap profesional dan ilmiah.

Mulyasa (2011) mengemukakan profesionalisme adalah mutu, kualitas, dan tindak tanduk yang merupakan ciri suatu profesi atau ciri orang yang profesional. Sementara kata profesional sendiri berarti: bersifat profesi, memiliki keahlian dan keterampilan karena pendidikan dan latihan, beroleh bayaran karena keahliannya itu. Menurut Pamungkas (2014) seorang profesional akan selalu mengadakan pelayanan atau mengabdi dilandasi kemampuan profesional serta filsafat yang mantap. Seorang yang profesional akan menampakkan adanya keterampilan teknis yang didukung oleh pengetahuan dan sikap kepribadian tertentu serta dilandasi oleh normanorma yang mengatur prilaku organisasi profesi.

Shafer dkk. (2002) menyatakan bahwa profesionalisme menjadi syarat utama bagi orang yang bekerja di sektor pelayanan publik. (p.59). Gambaran seseorang yang profesional dalam profesi dicerminkan dalam lima dimensi profesionalisme atau lebih dikenal dengan dimensi profesional Hall, yaitu sebagai berikut:

a) Pengabdian pada pekerjaan, dapat dicerminkan dari dedikasi dengan menggunakan pengetahuan dan kecakapan yang dimiliki serta keteguhan untuk tetap melaksanakan pekerjaan meskipun imbalan ekstrinsik kurang. Sikap ini adalah ekspresi dari pencurahan diri yang total terhadap pekerjaan.

b) Kewajiban sosial, merupakan pengertian tentang pentingnya peranan profesi serta manfaat yang diperoleh baik masyarakat maupun kalangan profesional lainnya karena adanya pekerjaan tersebut.

c) Kemandirian, diartikan sebagai suatu konsep bahwa seorang yang profesional harus mampu membuat keputusan sendiri tanpa tekanan dari pihak lain (pemerintah, klien dan mereka yang bukan anggota profesi). Setiap ada campur tangan dari luar dianggap sebagai hambatan kemandirian secara profesional.

d) Keyakinan terhadap pekerjaan, merupakan suatu keyakinan bahwa yang paling berwenang menilai apakah suatu pekerjaan yang dilakukan profesional atau tidak adalah rekan sesama pekerja, bukan pihak luar yang tidak 
mempunyai kompetensi dalam bidang ilmu dan pekerjaan tersebut.

e) Hubungan dengan sesama pekerjaan, adalah dengan menggunakan ikatan pekerjaan sebagai acuan, termasuk di dalamnya organisasi formal dan kelompok kolega informal sebagai ide utama dalam melaksanakan pekerjaan.

\section{Metode Penelitian}

Penelitian dilakukan di SD, SMP dan SMA Islam Terpadu Bina IImi Palembang. Populasi merupakan wilayah generalisasi yang terdiri atas obyek/subyek yang mempunyai kualitas dan karakteristik tertentu yang ditetapkan oleh peneliti untuk dipelajari dan kemudian ditarik kesimpulan. Populasi dalam penelitian berjumlah 116 orang Dihitung dengan rumus
Isaac dan Michael untuk populasi sebesar 116 orang dengan tingkat kesalahan 5\% maka jumlah sampel sebanyak 89 orang. Metode penarikan sampel pada penelitian ini adalah Non Probability sampling dengan tipe Cluster Sampling yaitu tehnik penentuan sampel apabila objek yang akan diteliti atau sumber data sangat luas. Penelitian ini merupakan penelitian asosiatif yaitu penelitian yang bertujuan untuk melihat pengaruh variabel independen dan variabel dependen serta dilengkapi dengan hipotesis, dengan teknik analisis data menggunakan analisis regresi linear berganda. Teknik pengumpulan data dengan menyebarkan angket berisi kuesioner pertanyaan terkait dengan variabel penelitian. Desain penelitian ini dapat dilihat pada gambar berikut ini:

Gambar 1.

Kerangka Pemikiran

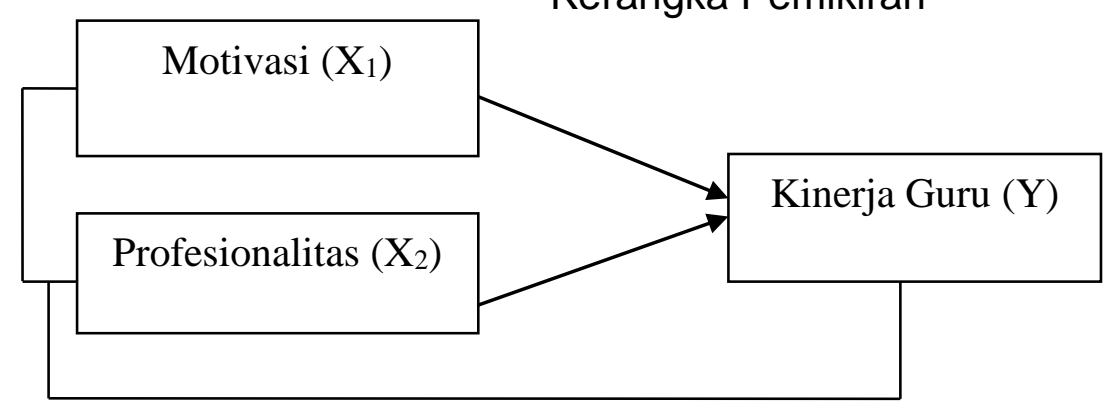

IV. Hasil Penelitian

\section{Hasil Uji Validitas dan Reliabilitas}

Hasil uji validitas dan reliabel variabel dalam penelitian ini dapat di lihat pada tabel berikut ini: 
Tabel 1

Hasil Uji Validitas dan Reliabilitas

\begin{tabular}{|c|c|c|c|c|c|}
\hline Item & $\begin{array}{c}\text { Corrected item } \\
\text { Motivasi }\end{array}$ & $\begin{array}{c}\text { Corrected item } \\
\text { Profesionalitas }\end{array}$ & $\begin{array}{c}\text { Corrected item } \\
\text { Kinerja }\end{array}$ & r Tabel & Keterangan \\
\hline Item 1 & 0,488 & 0,530 & 0,383 & & Valid \\
Item 2 & 0,391 & 0,408 & 0,442 & & Valid \\
Item 3 & 0,449 & 0,488 & 0,452 & & Valid \\
Item 4 & 0,403 & 0,548 & 0,487 & & Valid \\
Item 5 & 0,581 & 0,477 & 0,462 & 0,361 & Valid \\
Item 6 & 0,543 & 0,606 & 0,545 & & Valid \\
Item 7 & 0,475 & 0,747 & 0,414 & & Valid \\
Item 8 & 0,442 & - & 0,411 & & Valid \\
Item 9 & 0,420 & - & - & & Valid \\
Item 10 & 0,462 & - & - & & Valid \\
\hline
\end{tabular}

Berdasarkan hasil pengujian validitas dan reliabilitas pada tabel di atas dapat disimpulkan bahwa semua item masing-masing variabel di nyatakan valid karena nilai corrected item > 0,361 .

Tabel 2

Hasil Uji Reliabilitas

\begin{tabular}{|l|c|c|}
\hline \multicolumn{1}{|c|}{ Variabel } & $\begin{array}{c}\text { Cronbach's } \\
\text { Alpha } \\
\mathbf{0 , 7 0}\end{array}$ & Keterangan \\
\hline Motivasi Kerja $\left(\mathrm{X}_{1}\right)$ & 0,793 & Reliabel \\
Profesionalitas $\left(\mathrm{X}_{2}\right)$ & 0,807 & Reliabel \\
Kinerja Guru $(\mathrm{Y})$ & 0,747 & Reliabel \\
\hline
\end{tabular}

Hasil Uji reliabilitas pada Tabel 2 menunjukkan bahwa nilai Cronbach's Alpha untuk variabel motivasi kerja, profesionalitas dan kinerja > 0,70 artinya semua variabel dinyatakan valid.

\section{Hasil Uji Asumsi Klasik}

Hasil uji normalitas data dan hasil uji multikolinearitas dapat dilihat pada tabel berikut ini:

Tabel 3

Hasil Uji Normalitas Data dan Hasil Uji Multikolinearitas

\begin{tabular}{|l|c|c|c|c|}
\hline \multicolumn{1}{|c|}{ Variabel } & $\begin{array}{c}\text { Sig } \boldsymbol{\alpha}- \\
\mathbf{2} \text { tailed }\end{array}$ & $\begin{array}{c}\text { Keterang } \\
\text { an }\end{array}$ & $\begin{array}{c}\text { Toleran } \\
\text { ce }\end{array}$ & VIF \\
\hline Motivasi $\left(\mathrm{X}_{1}\right)$ & 0,269 & Normal & 0,986 & 1,015 \\
\hline Profesionalitas $\left(\mathrm{X}_{2}\right)$ & 0,722 & Normal & 0,987 & 1,015 \\
\hline Kinerja $(\mathrm{Y})$ & 0,944 & Normal & & \\
\hline
\end{tabular}

Hasil perhitungan pada Tabel 3 di atas diproleh nilai Sig $\alpha-2$ tailed $>$ sig a 0,05 maka disimpulkan bahwa semua data variabel terdistribusi 
normal. Hasil uji multikolinearitas diperoleh nilai Tolerance $>0,10$ dan nilai VIF < 10 maka semua variabel tidak terjadi multikolinearitas.

\section{Hasil Analisis Regresi Linear Berganda}

Hasil perhitungan analisis linear berganda dapat di lihat pada Tabel berikut ini:

Tabel 4

Hasil Analisis Linear Berganda

\begin{tabular}{|l|r|r|r|}
\hline \multirow{2}{*}{ Model } & \multicolumn{2}{|c|}{ Unstandardized Coefficients } & Standardized Coefficients \\
\cline { 2 - 4 } & \multicolumn{1}{|c|}{ B } & Std. Error & Beta \\
\hline (Constant) & $-0,068$ & 0,282 & \\
1 Motivasi Kerja (X1) & 0,527 & 0,074 & 0,552 \\
Profesionalitas (X2) & 0,348 & 0,075 & 0,362 \\
\hline
\end{tabular}

Nilai constant sebesar $-0,068$ dengan nilai variabel kerja sebesar 0,527 dan variabel profesionalitas sebesar 0,348. Artinya variabel bernilai positif dan peningkatan setiap satu satuan skor variabel motivasi dan profesionalitas dapat meningkatkan kinerja guru.

\section{Hasil Uji Hipotesis}

Hasil uji hipotesis untuk uji $\mathrm{F}$ dan uji $t$ dapat dilihat pada Tabel di bawah ini:

Tabel 5

Hasil Uji F

\begin{tabular}{|ll|r|r|r|r|r|}
\hline & Model & \multicolumn{1}{|c|}{$\begin{array}{c}\text { Sum of } \\
\text { Squares }\end{array}$} & df & \multicolumn{1}{c|}{$\begin{array}{c}\text { Mean } \\
\text { Square }\end{array}$} & \multicolumn{1}{c|}{ F } & Sig. \\
\hline 1 Regression & 6.481 & 2 & 2.160 & 12.644 & $.000^{\mathrm{a}}$ \\
Residual & 17.256 & 86 & .171 & & \\
Total & 23.737 & 88 & & & \\
\hline
\end{tabular}

Berdasarkan hasil perhitungan regresi linear berganda diperoleh nilai signifikan $F(0,000)<$ Sig $\alpha=0,05$ maka $\mathrm{H}_{0}$ ditolak artinya motivasi kerja dan profesionalitas secara simultan mempunyai pengaruh signifikan terhadap kinerja guru di Sekolah Islam Terpadu Palembang. Hasil uji hipotesis $\mathrm{t}$ dapat dilihat pada tabel berikut ini:

Tabel 6.

Hasil Uji Hipotesis t

\begin{tabular}{|c|c|c|c|c|c|}
\hline \multirow[b]{2}{*}{ Model } & \multicolumn{2}{|c|}{$\begin{array}{l}\text { Unstandardized } \\
\text { Coefficients }\end{array}$} & \multirow{2}{*}{$\begin{array}{c}\text { Standardized } \\
\text { Coefficients } \\
\text { Beta } \\
\end{array}$} & \multirow[b]{2}{*}{6} & \multirow[b]{2}{*}{ Sig. } \\
\hline & $B$ & Std. Error & & & \\
\hline 1 (Constant) &,- 068 & ,282 & &,- 241 & ,810 \\
\hline Motivasi & ,527 & ,074 & ,552 & 7,081 & ,000 \\
\hline Profesionalitas & ,348 & ,075 & ,362 & 4,643 &, 000 \\
\hline
\end{tabular}


Berdasarkan hasil perhitungan untuk motivasi kerja diperoleh nilai signifikansi sebesar $0,000<\operatorname{sig} \alpha$ $(0,05)$, artinya terdapat pengaruh signifikan motivasi kerja terhadap kinerja. Variabel profesionalitas dengan tingkat signifikansi sebesar $0,000<\operatorname{sig} \alpha(0,05)$, artinya terdapat pengaruh signifikan terhadap kinerja.

\section{Pembahasan}

\section{a) Pengaruh Motivasi Kerja terhadap Kinerja Guru Sekolah Islam Terpadu Bina IImi Palembang}

Hasil uji hipotesis t diperoleh nilai nilai signifikansi sebesar $0,000<\operatorname{sig} \alpha$ $(0,05)$, artinya terdapat pengaruh signifikan motivasi kerja terhadap kinerja guru. Dengan demikian, HO ditolak dan $\mathrm{Ha}$ diterima hipotesis penelitian yang menyatakan bahwa ada pengaruh signifikan motivasi kerja terhadap kinerja guru sekolah islam terpadu Bina IImi Palembang, dapat diterima.

Hal ini menunjukkan bahwa motivasi mempunyai pengaruh yang cukup penting dalam peningkatan kinerja guru. Motivasi sebagai suatu kehendak atau keinginan yang timbul dari dalam diri guru yang menyebabkan seorang guru berbuat dan bertindak untuk tujuan sekolah. Motivasi dapat diukur melalui adanya kebutuhan fisik, kebutuhan keamanan, kebutuhan sosial, penghargaan dan kepuasan diri. Hasil hipotesis menunuukkan adanya kesesuaian antara hipotesis dengan teori dan sekaligus menguatkan teori bahwa Lunerburg (2000: 88) yang menyatakan motivasi sebagai kekuatan berasal dari dalam dan luar diri seseorang, yang menstimulir, mengarahkan perilaku seseorang untuk melakukan suatu tindakan tertentu, demi proses pencapaian prestasi.

Hasil penelitian ini juga sejalan dengan penelitian Bungawati (2016) yang menyatakan bahwa terdapat pengaruh signifikan positif motivasi terhadap kinerja guru SMKN 7 Makassar sebesar 0,310 dengan nilai $p=0,004<0,005$.

Hasil penelitian ini berimplikasi dan bermakna bahwa variabel motivasi kerja mampu memberikan kontribusi pada peningkatan kinerja guru, semakin tinggi nilai motivasi dalam diri guru maka semakin tinggi juga performance dan prestasi kerja (kinerja) guru. Untuk itu perlu adanya pengakuan atas keberadaan guru di SIT Bina IImi melalui pemberian penghargaan bagi guru-guru berprestasi. Ciptakan rasa nyaman dan aman dalam diri guru baik dari segi fasilitas maupun hubungan relationship. Berikan ruang gerak bagi guru untuk berpotensi tumbuh mengembangkan karir.

\section{b) Pengaruh Profesionalitas terhadap Kinerja Guru Sekolah Islam Terpadu Bina IImi Palembang}

Hasil uji hipotesis t diperoleh nilai nilai signifikansi sebesar $0,000<\operatorname{sig} \alpha$ $(0,05)$, artinya terdapat pengaruh signifikan profesionalitas terhadap kinerja guru. Dengan demikian, HO ditolak dan $\mathrm{Ha}$ diterima hipotesis penelitian yang menyatakan bahwa ada pengaruh signifikan profesionalitas terhadap kinerja guru sekolah islam terpadu Bina IImi Palembang, dapat diterima.

Hasil di atas membuktikan hipotesis dan adanya kesesuaian hasil penelelitian, hipotesis dan teori yang dikemukan oleh Mulyasa (2011) 
profesionalisme adalah mutu, kualitas, dan tindak tanduk yang merupakan ciri suatu profesi atau ciri orang yang profesional. Sementara kata profesional sendiri berarti: bersifat profesi, memiliki keahlian dan keterampilan karena pendidikan dan latihan, beroleh bayaran karena keahliannya itu. Guru profosional adalah guru yang mampu melaksanakan kegiatan belajar dan pembelajaran berkualitas, sehingga memperoleh hasil kerja maksimal sesuai tujuan sekolah. bahwa profesionalitas guru sangatlah penting bagi peningkatan kinerja guru, yang ditandai dengan penguasaan kemampuan/kompetensi yang meliputi kompetensi pedagogik, kompetensi kepribadian, kompetensi sosial dan kompetensi profesional. Seorang guru harus mampu menguasai materi pelajaran yang diampunya sehingga proses pembelajaran dapat terlaksana secara efektif dan tepat sasaran.

Hasil penelitian ini mendukung penelitian Dewi (2015) hasil penelitiannya menunjukkan bahwa profesionalisme guru berpengaruh signifikan dan positif terhadap kinerja guru ekonomi SMA se Kota Malang dengan nilai sig t sebesar $(0,000)<$ sig $\alpha(0,05)$.

Implikasi hasil penelitian ini bahwa profesionalitas guru sangatlah penting bagi peningkatan kinerja guru, semakin tinggi tingkat profesionalitas guru maka makin tinggi juga tingkat kinerja, begitupun sebaliknya. Upaya untuk terus mampu profesional, maka guru hendaknya terus belajar dan inovasi dalam segala segi. Mengikuti berbagai pelatihan yang dapat mengembangkan kemampuan serta meningkatkan pendidikan ke jenjang lebih tinggi.

\section{Kesimpulan Dan Saran}

Berdasarkan hasil penelitian di atas disimpulkan variabel motivasi kerja diperoleh nilai signifikansi sebesar $0,000<\operatorname{sig} \alpha(0,05)$, artinya terdapat pengaruh signifikan motivasi kerja terhadap kinerja. Variabel profesionalitas dengan tingkat signifikansi sebesar $0,000<$ sig $\alpha$ $(0,05)$, artinya terdapat pengaruh signifikan terhadap kinerja.

Saran bagi pihak sekolah perlu adanya pengakuan atas keberadaan guru di SIT Bina IImi melalui pemberian penghargaan bagi guruguru berprestasi. Ciptakan rasa nyaman dan aman dalam diri guru baik dari segi fasilitas maupun hubungan relationship. Berikan ruang gerak bagi guru untuk berpotensi tumbuh mengembangkan karir. Upaya untuk terus mampu profesional, maka guru hendaknya terus belajar dan inovasi dalam segala segi. Mengikuti berbagai pelatihan yang dapat mengembangkan kemampuan serta meningkatkan pendidikan ke jenjang lebih tinggi.

\section{DAFTAR PUSTAKA}

Bungawati (2016). Pengaruh Kepemimpinan, Motivasi Kerja dan Disiplin Kerja terhadap Kinerja Guru SMKN 7 Makassar. Jurnal Competetitiveness. Vol.10 (2) Juli-Desember 2016. Hal:115.

Diakses dari:http://journal.unismuh.ac.id/in dex.php/competetitivenes.motiva si dan disiplin kerja

Dewi, Tiara Anggia (2015). Pengaruh Profesionalisme Guru dan Motivasi Kerja terhadap Kinerja Guru Ekonomi se-Kota Malang. Jurnal Promosi. Vol.3 (2). Hal: 24-35. 
Handoko, T.H. (2009). Manajemen Personalia dan Sumber Daya Manusia. Yogjakarta: BPFE

Hasibuan, S.P. Malayu (2014). Manajemen Sumber Daya Manusia. Edisi Revisi. Jakarta: Bumi Aksara.

Hikmat. (2011). Manajemen Pendidikan. (cet.2). Bandung, Indonesia: Pustaka Setia.

Lunerburg, Orstein. (2011). Educational Administration. Singapura: Wadworth.

Mangkunegara (2013). Manajemen Sumber Daya Manusia Perusahaan. Cetakan ke-11. Bandung: Remaja Rosdakarya.

Mudlofir, Ali. (2012). Pendidik Profesional. (cet.1). Jakarta, Indonesia: Rineka Cipta.

Mulyasa. (2011). Menjadi Guru Profesional, Menciptakan Pembelajaran Kreatif dan Menyenangkan. Bandung, Indonesia: Remaja Rosdakarya.

Pamungkas, Widyanggoro. Jabar, abdul. Cepi. (2014). Pengaruh Profesionalitas, Kepuasan Kerja, Iklim Organisasi terhadap Kinerja Guru SMKN di Kabupaten Boyolali. Jurnal Akuntabilitas Manajemen Pendidikan: Vol.2 (2): 265-278.
Rivai, Veitzhal. (2009). Manajemen Sumber Daya Manusia untuk Perusahaan. Jakarta, Indonesia: Rajawali Pers.

Rusman. (2010). Model-model Pembelajaran, Mengembangkan Profesionalisme Guru. Jakarta: Rajawali Pers.

Siagian, Pangabean (2008). Manajemen Sumber Daya Manusia. Cetakan VI. Jakarta: Bumi Aksara

Siswanto. (2007). Pengantar Manajemen. (cet.3). Jakarta, Indonesia: Bumi Aksara.

Shafer, William E.L.Jane Park \& Woody. (2002). Profesionalism, organizational-Profesional Conflict and Work Outcomes. American Sosiological Review.

Uno, B Hamzah. (2011). Teori Kinerja dan Pengukurannya. Cetakan pertama. Jakarta, Indonesia: Bumi Aksara

Wibowo. (2008). Manajemen Kinerja. (ed.3). Jakarta, Indonesia: RajaGrafindo Persada.

Widodo Eko, Suparno. (2015). Manajemen Pengembangan Sumber Daya Manusia. Yogyakarta, Indonesia: Pustaka Pelajar 